\title{
Lead (II)-Selective Polymeric Electrode Using PVC Membrane Based on a Schiff Base Complex of 1,2- Bis(Salicylidin Aminooxy) Ethane As an Ionophore
}

\author{
Ali Homafar ${ }^{1, *}$, Farzad Maleki ${ }^{2}$, Zahra Abbasi ${ }^{3}$ \\ ${ }^{1}$ Department of Chemistry, Eyvan-e-Gharb Branch, Islamic Azad University, Eyvan, Iran \\ ${ }^{2}$ Department of Chemistry, Payame Noor University, PO Box 19395-4697 Tehran, Iran \\ ${ }^{3}$ Young Researchers and Elite Club, Ilam Branch, Islamic Azad University, Ilam, Iran \\ *Corresponding Author: Alihomafar88@yahoo.com
}

Copyright @ 2013 Horizon Research Publishing. All rights reserved.

\begin{abstract}
A PVC membrane electrode for lead ion based on 1,2- bis(salicylidin aminooxy) ethane as a neutral carrier was prepared. The electrode exhibits a near Nernstion response (26/49 $\pm 0 / 7 \mathrm{mv} /$ decade) for lead ion over a relatively wide concentration rang $\left(1 / 0 \times 10^{-6}\right.$ to $\left.1 / 0 \times 10^{-1}\right)$ with a limit detection $7 / 6 \times 10-7 \mathrm{M}$. It has a releatively fast reasponse time $(<10 \mathrm{~s})$. The proposed membrane electrode revealed very good selectivity in the $\mathrm{PH}=4-7$. The influence of membrane composition enthe electrode response was studied. The proposed electrode was used for the determination of lead ion in wastewater, water and wastewater of manufactory.
\end{abstract}

Keywords Wastewater, PVC Membrane, Lead, Ion Selective Electrode, Schiff Bases

\section{Introduction}

Ion-selective sensors have been used for analytical determination of a wide variety of ions since the 1970s. Ion-selective sensor's utility and simplicity have replaced other wet analytical methods that were often far slower and more cumbersome to perform. Ionophore plays a key role in the sensitivity of an ion-selective electrode (ISE). The creation of cavities and cleft in the ionophore that are complementary to the size and charge of a particular ion can lead to very selective interactions. One of the most important figures of merit for ISEs is the selectivity towards a specific analyte, which is generally limited by the interaction of ionophore within the membrane with other ions in solution. Recently, there has been much focus on the construction of anion-selective electrodes that function on the basis of chemical recognition principle [1]. The demand for ionophores with either new or improved selectivities in the field of ionselective electrodes (ISEs) is high particularly in the area of anion-selective electrodes.
The ion-selective electrode (ISE) dynamic response is generated by the selective complexation of the target ion by the ion carrier that is dispersed in a poly(vinyl chloride) (PVC) matrix. The ISEs that are based on polymeric membranes incorporated with ionophores are well known to be very useful tools for clinical, chemical and environmental analysis. Until now, large numbers of ionophores with high selectivity for specific metal ions have been developed as potentiometric sensors for the determination of the respective metal ions. The ISEs for determining the lead ion have received much interest, and many ligands have been studied for their use as sensing ionophores[2-5]. Piroxicam, quinaldic acid, capric acid, diaza-crown, dibenzyl phosphate, benzyl sulfide, acyclic diamide, anthraquinone, calix-azo, calixphosphine oxides, thiacrown 5,5'-dithiobis-2-nitrobenzoic acid, crown-ethers and porphyrins as ionophores have been used for lead-ISEs[6-21]. The presence of toxic heavy metal ions in industrial wastewater has generated considerable concern in recent years. Heavy metal contamination exists in aqueous waste streams of many industries, such as metal plating facilities, mining operations and tanneries. The soils surrounding many military bases are also contaminated and pose a risk of metal ground water and surface water contamination. Among the toxic heavy metal ions which present potential danger to human health are copper, lead, cadmium, chromium and mercury [22-23]. These heavy metals are not biodegradable and tend to accumulate in living organisms, causing various diseases and disorders [24]. The feature of Schiff bases allow geometric and cavity control of the host-guest complexation and modulation of its lipophilicity, and this produces remarkable selectivity, sensitivity and stability for a specific ion. The resulting Schiff base complexes have attracted increasing attention in the field of ionic binding due to their unique properties and reactivity. In order to improve the selectivity for the lead ion compared with the other ions, we used a new Schiff base ionophore. Therefore in the present study, we describe 
the preparation and characterization of new ISEs that are based on as a Schiff base ionophore. The coordinating effect for the selective response of the lead ion was investigated by using PVC membranes. Polymeric ISEs provide one of the most powerful sensing methods because it is possible to select various sensory elements according to the shape and size of the target ion. The ISE based on 1,2-bis(salicylidinaminooxy) ethane exhibits good sensitivity and selectivity towards the lead ion.

\section{Experimental Section}

The 1,2- bis(salicylidin aminooxy) ethane that was tested as a lead(II) ionophore is shown in (Fig.1). The ionophore was synthesized by condensing 1,2-bis(aminooxy)ethane with salciylaldehyde with using a previously reported method. High molecular weight PVC, Dibuthyle sebacate (DBS), Dibutyle phthalate (DBP), Acetophenone (AP), Benzyle actate (BA) and Tetrahydrofuran (THF),Sodium tetraphenyl borate(NaTPB) were all obtained from Merck, and these substances were used to prepare the PVC membranes. The nitrate salts of the cations we used (all from Merck) were of the highest purity available. Doubly distilled water in a quartz apparatus was used to prepare all the aqueous electrolyte solutions. The typical composition of the PVC-based lead(II)-selective electrodes was $30 \mathrm{mg}$ PVC, $64 \mathrm{mg}$ plasticizer, $4 \mathrm{mg}$ ionophore and $2 \%$ additive. The ionophore, plasticizer, additive and PVC were dissolved in the appropriate volume of THF and this was mechanically stirred. All the membrane cocktails were cast in glass rings placed on glass plates for creating the conventional ion-selective electrodes. The solvent from the PVC membrane was allowed to evaporate for at least 24 hours at room temperature (Fig.2). The thickness of the resulting membrane, as measured by a micrometer, was about $0.3 \mathrm{~mm}$. The tube was then filled with internal filling solution $\left(1 \times 10^{-3} \mathrm{M}\right) \mathrm{Pb}\left(\mathrm{NO}_{3}\right)_{2}$. The electrode was finally conditioned for $24 \mathrm{~h}$ by soaking in a $1 \times 10^{-2} \mathrm{M}$ solution of lead(II) nitrate. A silver/silver chloride electrode was used as an internal reference electrode. The ratio of various ingredients, concentration concentration of equilibrating solutions, and time of conditioning were optimized in order we have reproducible membranes and the potentials with relatively little noise. The composition of the membrane electrode is summarized in Table1.

All emf measurements were carried out with the following cell assembly: Ag/AgCl|3MKCl|sample solution |electrode embrane $|1.0 \times 10-3 \mathrm{MPb}(\mathrm{NO} 3) 2| 3 \mathrm{MKCl} \mid \mathrm{Ag} / \mathrm{AgCl}$ (Fig.3).

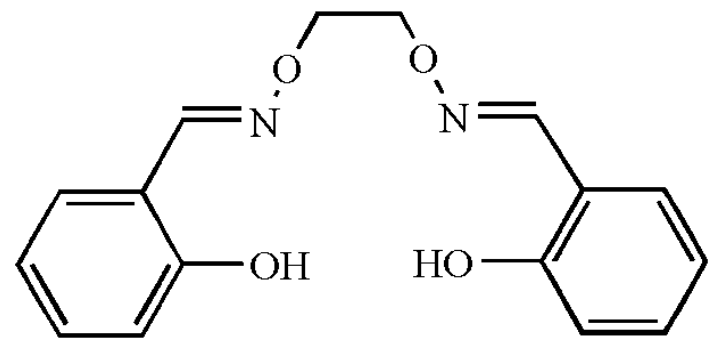

Figure1. structure of ionophore 1,2- bis(salicylidin aminooxy)ethane

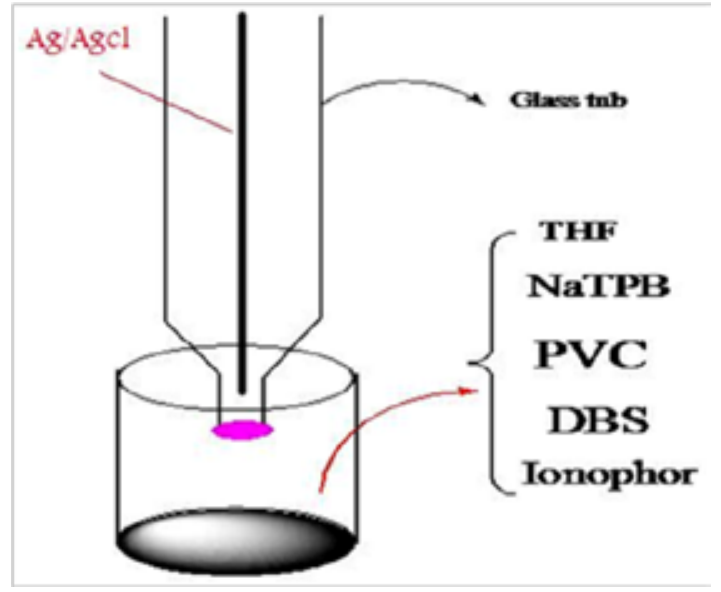

Figure 2. Membrane electrode structure made

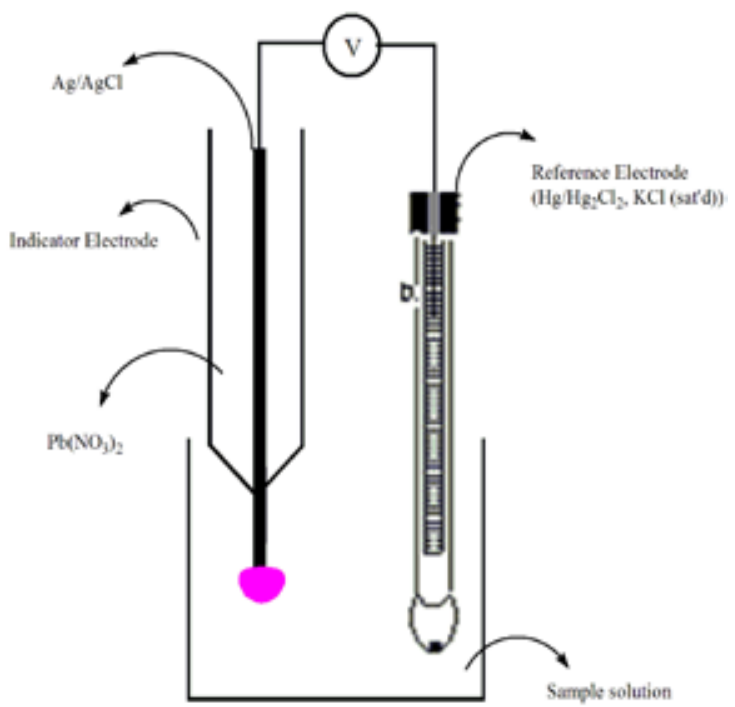

Figure 3. structure of Ion-selective 
Table1. Optimization of membrane ingredients of $\mathrm{Pb}^{2+}$-selective electrode.

\begin{tabular}{|c|c|c|c|c|c|c|}
\hline \multirow{2}{*}{ No } & \multicolumn{4}{|c|}{ Composition (w/w, \%) } & \multirow{2}{*}{$\begin{array}{l}\text { Slope (mV decade-1 } \\
\text { of activity) }\end{array}$} & \multirow{2}{*}{$\mathrm{LOD}^{\mathrm{a}}$} \\
\hline & Ionophore(fig.1) & $\underline{\mathrm{PVC}}$ & Plasticizer & $\underline{\mathrm{NaTPB}}$ & & \\
\hline 1 & 0 & 30 & 68(DBS) & 2 & N.M. & N.M. \\
\hline 2 & 2 & 30 & 66(DBS) & 2 & 15.0 & -5.22 \\
\hline 3 & 3 & 30 & 65(DBS) & 2 & 20.9 & -4.25 \\
\hline 4 & 3.5 & 30 & 64.5(DBS) & 2 & 23.2 & -5.14 \\
\hline 5 & 4 & 30 & 64(DBS) & 2 & 26.49 & -5.18 \\
\hline 6 & 4.5 & 30 & 63.5(DBS) & 2 & 21.9 & -5.23 \\
\hline 7 & 2 & 30 & 66(DBP) & 2 & 9.5 & -5.15 \\
\hline 8 & 2 & 30 & 66(AP) & 2 & 3.7 & -3.40 \\
\hline 9 & 2 & 30 & 66(BA) & 2 & 2.4 & -5.30 \\
\hline
\end{tabular}

${ }^{\mathrm{a}}$ limit of detection(LOD) of log a (M)

Table 2. Selectivity coefficients ( $\log _{P b^{2+, j}}^{P o t}$ ) for the various different lead ion selective electrodes, No.4 in Table 1)

\begin{tabular}{|c|c|c|c|c|c|c|c|}
\hline $\begin{array}{l}\text { Interference } \\
\quad \text { ion }\end{array}$ & $\begin{array}{l}\text { Capric } \\
\text { Acid }\end{array}$ & Piroxicam & $\begin{array}{l}\text { Dibenzyl } \\
\text { phosphate }\end{array}$ & $\begin{array}{c}\text { Calix } \\
\text { phosphine } \\
\text { oxide } \\
\end{array}$ & $\begin{array}{l}\text { Schiff base } \\
\text { BSPD }\end{array}$ & $\begin{array}{c}\text { Schiff base } \\
\text { BTEA }\end{array}$ & $\begin{array}{c}\text { This work. 1,2- } \\
\text { bis(salicylidin } \\
\text { aminooxy)ethane }\end{array}$ \\
\hline $\mathrm{Cu}^{2+}$ & 2.3 & 1.9 & 4.5 & 4.3 & 2.7 & 3.3 & 1.3 \\
\hline $\mathrm{Ba}^{2+}$ & 2.3 & 2.2 & * & * & 3.1 & 2.6 & 1.3 \\
\hline $\mathrm{Cd}^{2+}$ & 2.6 & 2.3 & 3.2 & 5.3 & 3.6 & 3.4 & 1.3 \\
\hline $\mathrm{Sr}^{2+}$ & $*$ & 2.3 & $*$ & 4.2 & 3.8 & 4.1 & 1.5 \\
\hline $\mathrm{Zn}^{2+}$ & 2.7 & 2.9 & 5.2 & 4.5 & 4.1 & 3.7 & 1.8 \\
\hline $\mathrm{Ca}^{2+}$ & $*$ & 4 & 2.3 & 2.3 & 4.1 & 4 & 1.5 \\
\hline $\mathrm{Mg}^{2+}$ & $*$ & 2.4 & $*$ & $*$ & 4.9 & 4.6 & $x$ \\
\hline $\mathrm{Na}^{+}$ & 1.2 & 1.4 & 3.5 & 0.8 & 2.5 & 3.2 & 1.5 \\
\hline $\mathrm{K}^{+}$ & 1.1 & 2.2 & 2.8 & 2.5 & 2.2 & 3.1 & 1.6 \\
\hline $\mathrm{Mn}^{+2}$ & $x$ & $x$ & $x$ & $x$ & $x$ & $x$ & 1.47 \\
\hline $\mathrm{Ni}^{2+}$ & $x$ & $x$ & $x$ & $x$ & $x$ & $x$ & 2 \\
\hline $\mathrm{Ce}^{+3}$ & $x$ & $x$ & $x$ & $x$ & $x$ & $x$ & 2.9 \\
\hline $\mathrm{Al}^{+3}$ & $x$ & $x$ & $x$ & $x$ & $x$ & $x$ & 2.1 \\
\hline $\mathrm{Co}^{+2}$ & $x$ & $x$ & $x$ & $x$ & $x$ & $x$ & 1.5 \\
\hline $\mathrm{Ag}^{+}$ & $*$ & 0.5 & 0.1 & 0.2 & 2.2 & 3.5 & 1.8 \\
\hline $\mathrm{Bi}^{+2}$ & $x$ & $x$ & $x$ & $x$ & $x$ & $x$ & 1.9 \\
\hline $\mathrm{Fe}^{3+}$ & $x$ & $x$ & $x$ & $\times$ & $x$ & $\times$ & 2.1 \\
\hline $\mathrm{Cr}^{3+}$ & $x$ & $x$ & $x$ & $x$ & $x$ & $x$ & 2.3 \\
\hline $\mathrm{NH}^{4+}$ & $x$ & $x$ & $x$ & $x$ & $x$ & $x$ & 1.8 \\
\hline Refernce & [11] & [13] & [18] & [19] & [25] & {$[26]$} & --- \\
\hline
\end{tabular}


Table 3. Comparison of the $\mathrm{Pb}^{+2}$ selective electrodes with reported electrodes

\begin{tabular}{|c|c|c|c|c|c|c|}
\hline Ionophore & $\begin{array}{c}\text { Respon } \\
\text { (mv/ decade) }\end{array}$ & $\begin{array}{c}\text { Working } \\
\text { concentratio } \\
\text { n range(M) }\end{array}$ & $\begin{array}{l}\text { Detection } \\
\text { limit(M) }\end{array}$ & $\begin{array}{l}\text { Respons } \\
\text { e time(S) }\end{array}$ & $\begin{array}{l}\text { Selectivity } \\
\text { coefficiens } \\
\left(\mathrm{k}_{\mathrm{Pb}^{+2}}^{\mathrm{pot}}\right)\end{array}$ & Refernce \\
\hline $\begin{array}{l}\text { Bis(acetylacetone)-p-phenylenediam } \\
\text { ine-lead(II)[LPb(NO3)2]H2O } \\
\text { complex ionohore }\end{array}$ & 30 & $\begin{array}{l}1 \times 10^{-1} \\
1 \times 10^{-5}\end{array}$ & $2 \times 10^{-6}$ & $10<$ & & 5 \\
\hline $\begin{array}{c}\text { N,N'-bis(5-methyl } \\
\text { salicylidene)-p-diphenylene } \\
\text { methane diamine }\end{array}$ & $29 / 4$ & $\begin{array}{l}1 \times 10^{-1} \\
5 \times 10^{-6}\end{array}$ & $2 \times 10^{-6}$ & $10<$ & $\begin{array}{l}\mathrm{Zn}^{+2}, \mathrm{Fe}^{+3} \\
\mathrm{~K}^{+}, \mathrm{NH}^{+}\end{array}$ & 27 \\
\hline $\begin{array}{l}\text { N,N'-bis(3-methyl } \\
\text { salicylidene)-p-henylene methane } \\
\text { diamine }\end{array}$ & $30 / 3 \pm 0 / 6$ & $\begin{array}{l}1 \times 10^{-1} \\
2 \times 10^{-5}\end{array}$ & $1 \times 10^{-5}$ & $10<$ & $\begin{array}{l}\mathrm{K}^{+}, \mathrm{NH}^{+}, \\
\mathrm{Na}^{+}\end{array}$ & 28 \\
\hline $\begin{array}{c}\text { 1,10-dibenzyl-1,10-diaza-18-crowne } \\
-6 \\
\end{array}$ & $29 / 1,28 / 9$ & $\begin{array}{l}1 \times 10^{-1} \\
5 \times 10^{-6} \\
\end{array}$ & $\begin{array}{l}3 \times 10^{-6} \\
5 \times 10^{-6}\end{array}$ & $10<$ & $\mathrm{Cd}^{+2}, \mathrm{Cu}^{+2}$ & 29 \\
\hline $\begin{array}{l}\text { N,N'-bis-thiophene-2-ylmethylene- } \\
\text { ethane-1,2- diamine }\end{array}$ & 29.79 & $\begin{array}{l}1 \times 10^{-1} \\
1 \times 10^{-5}\end{array}$ & $2 / 04 \times 10^{-6}$ & $10<$ & & 26 \\
\hline $\begin{array}{c}\text { N,N'-bis(salicylidene)-2,4-pyridined } \\
\text { iamine } \\
\end{array}$ & 29.4 & $\begin{array}{l}1 \times 10^{-1} \\
1 \times 10^{-6} \\
\end{array}$ & $10^{-6 / 04}$ & $10<$ & $\mathrm{K}^{+}, \mathrm{Ag}^{+}$ & 30 \\
\hline Schiff base as a neutral carrir & $29.4 \pm 0 / 5$ & $\begin{array}{l}1 \times 10^{-1} \\
1 \times 10^{-5}\end{array}$ & $5 \times 10^{-6}$ & $10<$ & $\mathrm{K}^{+}, \mathrm{Na}^{+}, \mathrm{Cu}^{+2}$ & 31 \\
\hline $\begin{array}{c}\text { N,N'-dibenzyl-1,4,10,13-tetraoxa-7, } \\
\text { 16-diazacyclooctadecane(I) }\end{array}$ & $30 \pm 0 / 1$ & $\begin{array}{r}1 \times 10^{-1} \\
8.2 \times 10^{-6} \\
\end{array}$ & $8 / 2 \times 10^{-6}$ & $10<$ & $\mathrm{Cd}^{+2}, \mathrm{Cu}^{+2}, \mathrm{Ag}^{+}$ & 32 \\
\hline $\begin{array}{c}\text { This work. 1,2- bis(salicylidin } \\
\text { aminooxy)ethane }\end{array}$ & $26.49 \pm 0 / 7$ & $\begin{array}{l}1 \times 10^{-1} \\
1 \times 10^{-6} \\
\end{array}$ & $7 / 6 \times 10^{-7}$ & $10<$ & $\begin{array}{c}\mathrm{Al}^{+3}, \mathrm{Ce}^{+3}, \mathrm{Ni}^{2+}, \mathrm{Cr}^{3+}, \\
\mathrm{Fe}^{3+}\end{array}$ & \\
\hline
\end{tabular}

\section{Results and Discussion}

Schiff bases as ligands seem to have potential to serve as ionophores for soft heavy metal ions in the PVC membrane electrodes because of their excellent metal-binding properties, their water insoluble and their rapid exchange kinetics. The Schiff base of 1,2- bis(salicylidin aminooxy)ethane was used as an ionophore for preparing the PVC membrane ion-selective electrodes for a wide variety of metal ions. Table 1 shows the compositions of the ionophore, the plasticizer, the additive and the PVC. Figure 4 shows the $\mathrm{pH}$ dependence for the potentiometric response of the novel membrane electrode in a variety of $\mathrm{pH}$ solutions. It is clear from Fig. 4 That the potentials were found to stay constant from $\mathrm{pH} 4$ to 7 , beyond which the potential changes considerably. The sharp change in potentials at higher $\mathrm{pH}$ values may be due to the hydrolysis of the $\mathrm{Pb}^{2+}$ ions to form lead hydroxide while at lower $\mathrm{pH}$ values, there is an increase in potential of the electrode which indicates that the sensor responds to hydrogen ions. The $\mathrm{Pb}^{2+}$-ISE membrane compositions were optimized to obtain the best sensitivity and selectivity towards the lead ion because the sensitivity and selectivity of the ion-selective electrodes were dependent upon the nature of ionophore used, as well as being significantly dependent on the membrane composition and the additives that were used. The optimization was carried out by varying the ratio of the PVC membrane components such as the PVC, the plasticizer, the ionophore and the additive (NaTPB). The potentiometric response of the membranes was evaluated as to the slope and the detection limit towards the lead ion. The effects of the membrane composition, the nature ofplasticizers, the ionophores and the lipophilic additive on the potentiometric response of the $\mathrm{Pb}^{2+}$-ISE were investigatedand the results are summarized in Table 1 . A membrane prepared displays a good Nernstian response to $\mathrm{Pb} 2+$ over a wide range. The slope of the calibration curve was $26.49 \mathrm{mV} /$ decade of the $\mathrm{Pb}^{2+}$ concentration at room temperature, and the limit of detection (LOD) of the log a (M) was equal to -5.18 . The effect of the plasticizer on the $\mathrm{Pb}^{2+}$ ISE membrane electrodes based on the Schiff base is shown in Figure 5. The response time of the membrane electrode thus obtained was $<5 \mathrm{~s}$ for the addition of $1.0 \times$ $10^{-3} \mathrm{M} \mathrm{Pb}^{2+}$ to the $1.0 \times 10^{-2} \mathrm{M}$ lead ion (Fig.6). The potentiometric selectivity coefficients measure the response of the electrode for the primary ion in the presence of foreign ions (Table 2). That shows potentiometric selectivity coefficient data of $\mathrm{Pb}(\mathrm{II})$-selective electrode for interferingcations relative to $\mathrm{Pb}^{2+}$, which indicate that the ISE is selective towards lead over the transition metal, alkali and alkaline earth metals, and other heavy metal ions. The optimized formulation of the sensor no. 5 was compared in terms of analytical performance with membranes employing different neutral ionophores that had been studied previously. Table 3 represents the main analytical features of some Lead(II) ionselective electrodes. The sensor is superior to existing sensors in terms of selectivity over anumber of cations whilecomparable with regard to other parameters such as working concentration range, slope, $\mathrm{pH}$ range, response time and reproducibility. 
Further, this sensor could be used in real sample analysis.

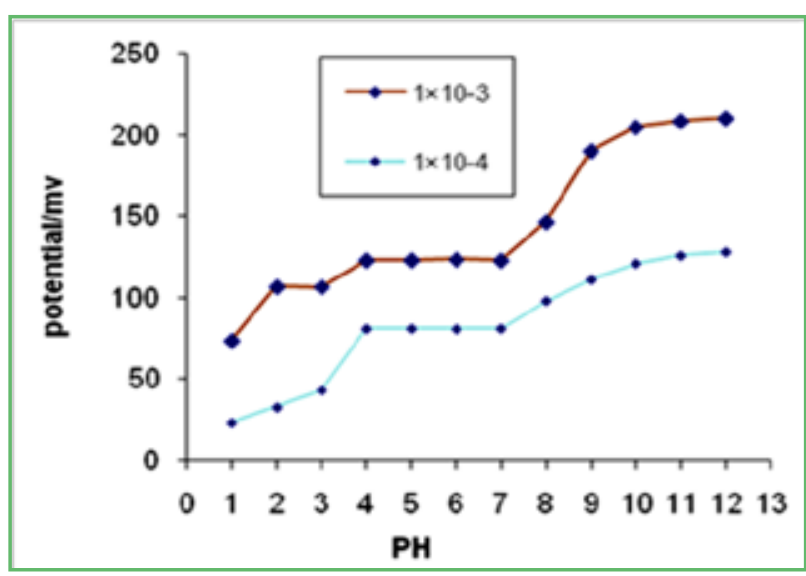

Figure 4. Effect of $\mathrm{PH}$ on the potential response the $\mathrm{Pb}^{+2}$ ion- selective electrode at two different: $1 \times 10^{-3}, 1 \times 10^{-4}$

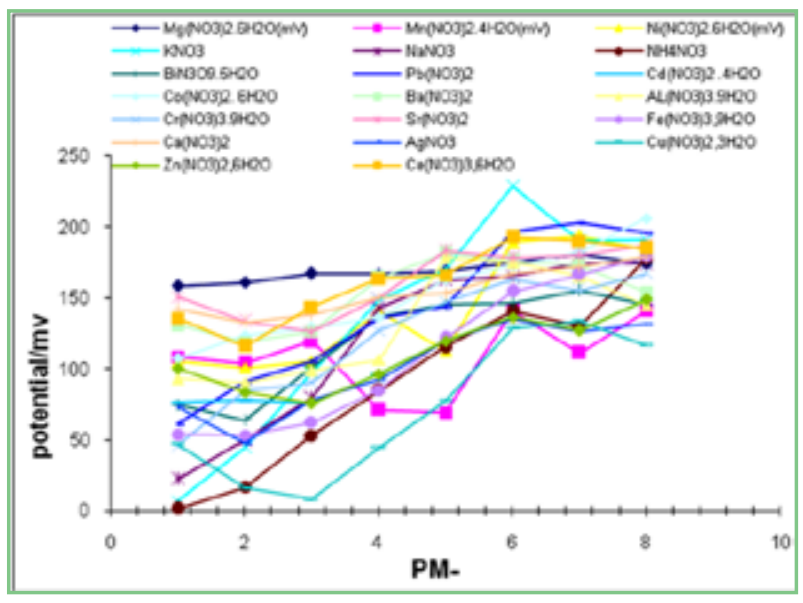

Figure 5. electrode The lead-ion responses of the membranes prepared by using different $\%$ of plasticizers and the ionophore. (conditions: electrode number 5 in Table 1 and concentration of lead in test solutions was $\left.10^{-3} \mathrm{~mol} \mathrm{~L}^{-1} \mathrm{~Pb}(\mathrm{NO} 3)_{2}\right)$.

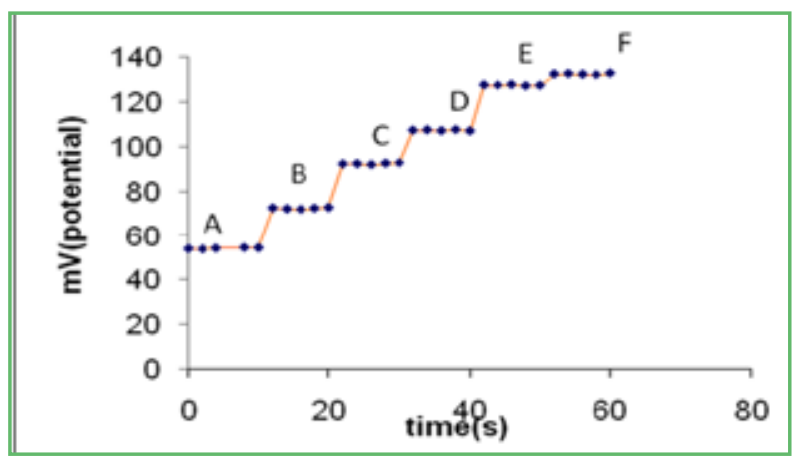

Figure 6. Dyanamic response tim of the membrane electrode based on ionophore1,2- bis(salicylidin aminooxy)ethane for step change in concentration of $\mathrm{Pb}^{+2}$.(A) $1 \times 10^{-2}$, ( B) $1 \times 10^{-3}$, (C) $1 \times 10^{-4}$,(D) $1 \times 10^{-5}$, (E) $1 \times 10^{-6},(\mathrm{~F}) 1 \times 10^{-7}$

\section{Conclusions}

The membrane electrode incorporating 1,2bis(salicylidinaminooxy)ethane as an ion carrier can be used for the development of a lead ion-selective electrode. The membrane has a linear dynamic range between $1.0 \times$ $10^{-1} \mathrm{M}-1.0 \times 10^{-6} \mathrm{M}$ with a Nernstian slope of $26.49 \mathrm{mV}$ per decade, and its detection limit was $7.6^{*} 10^{-7} \mathrm{M}$. The potentiometric response is independent of $\mathrm{PH}$ range of 4-7. Most of the metal ions would not seriously affect the selectivity of the lead electrode. It can be concluded that the membrane electrode has a rapid potential response and excellent selectivity towards the lead ion over the other interfering metal ions.

\section{REFERENCES}

[1] E. Bakker, E. Malinowaska, R.D. Schiller, M.E. Meyerhoff, Talanta 41 (1994) 881.

[2] Abbaspour, A.; Khajeh, B. Anal. Sci. 2002, 18, 987.

[3] Gupta, V. K.; Mangla, R.; Agarwal, S. Electroanalysis 2002, $14,1127$.

[4] Rouhollahi, A.; Ganjali, M. R.; Shamsipur, M. Talanta 1998, 46,1341 .

[5] Zareh, M. M.; Ghoneim, A. K.; Abd El-Aziz, M. H. Talanta 2001,54, 1049.

[6] Lu, J.; Chen, R.; He, X. Talanta 2002, 528, 33.

[7] Tavakkoli, N.; Khojasteh, Z.; Sharghi, H.; Shamsipur, M. Anal.Chim. Acta 1998, 360, 203.

[8] Ohki, A.; Kim, J. S.; Suzuki, Y.; Hayashita, T.; Maeda, S. Talanta1997, 44, 1131.

[9] Abbaspour, A.; Tavakol, F. Anal. Chim. Acta 1999, 378, 145.

[10] Mousavi, M. F.; Sahari, S.; Alizadeh, N.; Shamsipur, M. Anal..Chim. Acta 2000, 414, 189.

[11] Shamsipur, M.; Ganjali, M. R.; Rouhollahi, A. Anal. Sci. 2001,17, 935.

[12] Casado, M.; Daunert, S.; Valiente, M. Electroanalysis 2001, 13,54 .

[13] Sadeghi, S.; Dashti, G. R.; Shamsipur, M. Sensors and ActuatorsB 2002, 81, 223.

[14] Srivastava, S. K.; Gupta, V. K.; Jain, S. Analyst 1995, 120, 495.

[15] Riahi, S.; Mousavi, M. F.; Shamsipur, M.; Sharghi, H.Electroanalysis 2003, 19, 1561.

[16] Fathi, M. R.; Darviche, F.; Ganjali, M. R. Anal. Lett. 2000, 30,1025.

[17] Mousavi, M. F.; Barzegar, M. B.; Sahari, S. Sensors and ActuatorsB 2001, 73, 199.

[18] Xu, D.; Kastu, T. Anal. Chim. Acta 1999, 401, 111. 
[19] Cadogan, F.; Kane, P.; McKervey, M. A.; Diamond, D. Anal.Chem. 1999, 71, 5544.

[20] Rouhollahi, A.; Ganjali, M. R.; Shamsipur, M. Talanta 1998, 46,1341 .

[21] Lee, H. K.; Song, K. J.; Seo, H. R.; Choi, Y.-K.; Jeon, S. Sensorsand Actuators B 2004, 99, 323.

[22] Bailey,S.E.,Olin,T.J.,Bricka,R.M.,Adrian,D.D., Water Res.33(11), 1999.2469.

[23] Gloaguen, V., Morvan, H., J.Environ.Sci.Health A32 (4)1997, 901.

[24] Bulut, Y., Baysal, Z, J.Environ.Manage, 78, 2006,107.

[25] H. A. Arida, S. A. El-Reefy, A. M. El-Saied, Anal. Sci. 19, 687 (2003).
[26] T. Jeong, D. C. Jeong, H. K. Lee, and S. Jeon, Bull. Korean Chem. Soc. , Vol. 26, No. 81219 (2005).

[27] M. M. Ardakany, A. A. Ensafi, H. Naeimi, A. Dastanour, A. Shamlli. Sens. Actuators B, 96, 441(2003).

[28] M. M. Ardakany, A. A. Ensafi, H. Naeimi, A. Dastanour, A. Shamlli. Russ. J. Electrochem.39, 269(2003).

[29] M. M. Ardakany, M. K. Kashani, M. Salavati-Niasari, A. A. Ensafi, Sens. Actuators B, 107, 438 (2005).

[30] T. Jeong, H.K. Lee, D. C. Jeong, S. Jeon. Talanta,65,543(2005).

[31] M. M. Ardakany, P. Pourhakak, M. Salavati-Niasari. Anal. Sci. 22,865 (2006).

[32] V. K. Gupta, A. K. Jain, P. Kumar, Sens. Actuators B, 120, 259 (2006). 